\title{
PENGARUH KOMPETENSI APARATUR PEMERINTAH TERHADAP KUALITAS PELAYANAN PUBLIK PADA KANTOR KECAMATAN SANGATTA SELATAN KABUPATEN KUTAI TIMUR
}

Oleh : Eli Ampung dan Salasiah

Fakultas Ilmu Sosial dan Ilmu Politik

Universitas 17 Agustus 1945 Samarinda

\begin{abstract}
This research is based on the competence of government apparatus in southern Sangatta kecmatan in hopes to improve the quality of public services.

The purpose of this study is to determine whether the competence of the government apparatus affect the quality of public services at the district office very districts kutai east. The type of research or explanation used is descriptive kuanlitatif used to analyze the relationship between research variables. Types of data used are kusioner, observation, interview, and documentation.

The result of partial test on the independent variable that is the Competence variable of government apparatus toward the variable of public service quality shows the result that have significant influence that is by showing from $t$ count $>t$ table, 3.304> 1675. With R obtained for 0.776, which means that $77.6 \%$ Competence the government apparatus has a positive impact on service quality and $22.4 \%$ is influenced by other factors not discussed in this study.
\end{abstract}

Keywords: competence of government apparatus

\section{PENDAHULUAN}

\section{A. Latar Belakang}

Kualitas layanan pada suatu organisasi atau lembaga apabila dikelola dengan tepat akan berkontribusi positif terhadap terwujudnya kepuasan dan loyalitas masyarakat. Lewis dan Booms dalam Fandy Tjiptono (2011:157) menyatakan, "Kualitas layanan sebagai ukuran seberapa bagus tingkat layanan yang diberikan mampu sesuai dengan ekspektasi pelanggan". Sedangkan Parasuraman dalam Fandy Tjiptono (2011:157) mengatakan, "Faktor utama yang mempengaruhi kualitas layanan adalah layanan yang 
diharapkan pelanggan (expected service) dan persepsi terhadap layanan (perceived service)".

Pelayanan jasa banyak dilakukan oleh berbagai organisasi baik organisasi swasta maupun lembaga pemerintahan. Bentuk layanan pada lembaga pemerintahan sangat banyak diantaranya layanan yang berhubungan dengan administrasi negara, antara lain dalam pembuatan dokumen-dokumen penting seperti kartu identitas, sertifikat kepemilikan suatu barang, dan lain sebagainya.

Kantor Kecamatan Sangatta adalah salah satu kantor kecamatan di Kabupaten Kutai Timur. Di kantor tersebut banyak kegiatan yang dilakukan, salah satunya adalah layanan administrasi masyarakat. Bentuk layanan yang ada di kecamatan antaralain pembuatan kartu tanda penduduk (KTP), kartu keluarga (KK), akta kelahiran, legalisasi beberapa dokumen atau data dan lain sebagainya. Surat-surat tersebut sangat penting untuk dimiliki. Salah satu surat yang wajib dimiliki setiap keluarga di Indonesia yaitu kartu keluarga.

Kartu keluarga merupakan kartu identitas keluarga yang memuat data lengkap tentang susunan, hubungan dan jumlah anggota keluarga. Setiap terjadi perubahan data keluarga yang dikarenakan kelahiran, kematian maupun perpindahan maka kepala keluarga wajib melaporkan hal tersebut kepada Kepala Desa dan akan diterbitkan kartu keluarga yang baru.

Observasi awal yang dilakukan peneliti di kantor Kecamatan Sangatta pada tanggal 15 Oktober 2017 yaitu mengenai pelayanan pembuatan kartu keluarga. Beberapa pengunjung yang mengurus pembuatan kartu keluarga di Kecamatan Sangatta menilai bahwa pelayanan yang diberikan kurang memberikan kepuasan. Pengunjung tersebut mengungkapkan bahwa jam kerja kecamatan yang seharusnya dimulai pukul 07.00 WIB tetapi baru dibuka pukul 8.45 WIB. Selain itu pelayanan yang diberikan juga membutuhkan waktu yang lama. Hal tersebut sesuai dengan pengamatan langsung peneliti ketika melakukan observasi, terlihat bahwa pada umumnya pegawai yang datang terlambat tetapi pulang lebih cepat dari jam kantor. Pegawai kecamatan seharusnya mulai bekerja pukul 07.00 WIB sampai 16.00 WIB pada hari Senin - Kamis dan pukul 07.00 sampai 11.00 WIB pada hari Jumat, tetapi pada saat peneliti melakukan observasi pada pukul 08.30 WIB hanya beberapa pegawai yang sudah hadir. Jam pulang pegawai yang seharusnya berakhir pada pukul 16.00 WIB ternyata sebelum pukul 16.00 WIB ada beberapa pegawai sudah meninggalkan kantor.

Pembahasan disiplin pegawai dalam manajemen sumber daya manusia berawal dari pandangan bahwa tidak ada manusia yang sempurna, luput dari kekhilafan dan kesalahan. Oleh karena itu, setiap organisasi perlu memiliki berbagai ketentuan atau peraturan yang harus ditaati oleh para pegawai atau pegawainya. Menurut Sondang P. Siagian (2003:305), 
"Disiplin merupakan tindakan manajemen untuk mendorong para anggota organisasi memenuhi tuntutan berbagai ketentuan tersebut". Sedangkan

Abdurahmat Fathoni (2006:172) menyatakan, "Kedislipinan sebagai kesadaran dan kesediaan seseorang menaati semua peraturan perusahaan dan norma-norma sosial yang berlaku". Dengan kata lain pendislipinan pegawai merupakan suatu bentuk pelatihan yang berusaha memperbaiki dan membentuk pengetahuan, sikap dan perilaku pegawai sehingga para pegawai tersebut secara sukarela berusaha bekerja secara kooperatif dengan para pegawai yang lain serta meningkatkan prestasi kerjanya.

Kurang sigapnya pegawai dan kedislipinan pegawai yang masih rendah terlihat pada pengamatan yang dilakukan peneliti, misalnya ketidaktepatan dalam kehadiran, tidak berangkat kerja tanpa ijin tertulis dan jam istirahat yang tidak digunakan semaksimal mungkin. Selain itu waktu pembuatan kartu keluarga yang biasanya memakan waktu 1 sampai 2 hari atau bahkan lebih, padahal bisa selesai dalam waktu 45 menit sampai satu jam jika masyarakat yang ingin membuat kartu keluarga bersedia menunggu di tempat. Hal tersebut memungkinkan terjadinya penurunan kualitas pelayanan karena tingkat kedisiplinan dalam penggunaan waktu tidak sesuai dengan jam kerja yang telah ditetapkan. Hal tersebut menunjukkan kurang adanya kedisiplinan pada kantor kecamatan dengan baik.

Berhasil tidaknya kualitas layanan tergantung pada kemampuan organisasi atau perusahaan dan stafnya memenuhi harapan masyarakat secara konsisten. Oleh karena itu, sumber daya manusia memegang peranan penting dalam kegiatan layanan di kantor kecamatan. Dalam penelitian ini sumber daya manusia yang dimaksud adalah kompetensi pegawai dalam organisasi

\section{B. Permasalahan}

"Pengaruh Kompetensi Aparatur Pemerintah Terhadap Kualitas Pelayanan Publik pada Kantor Kecamatan Sangatta Kabupaten Kutai Timur".

\section{Tujuan Penelitian}

Untuk mengetahui "Pengaruh Kompetensi Aparatur Pemerintah Terhadap Kualitas Pelayanan Publik pada Kantor Kecamatan Sangatta Kabupaten Kutai Timur".

\section{METODE PENELITIAN}

Jenis penelitian ini adalah penelitian survey. Penelitian survey adalah penelitian yang dilakukan pada populasi besar maupun kecil, tetapi data yang dipelajari adalah data dari sampel yang diambil dari populasi tersebut, 
sehingga ditemukan kejadian-kejadian relatif, distribusi dan hubungan antar variabel. Metode yang digunakan dalam penelitian ini adalah metode kuantitatif.

Suharsimi (2006:12) mengemukakan bahwa, "Penelitian kuantitatif banyak menggunakan angka, mulai dari pengumpulan data, penafsiran terhadap data tersebut, serta penampilan dari hasilnya". Selain itu pemahaman akan kesimpulan penelitian akan lebih baik apabila juga disertai dengan tabel, grafik, bagan, gambar, atau tampilan lainnya.

Penggunaan penelitian kuantitatif dalam hal ini bertujuan untuk mengetahui pengaruh kompetensi aparatur pemerintah terhadap kualitas pelayanan publik sub bagian tata pemerintahan pada pembuatan kartu keluarga (KK), kaartu tanda penduduk (KTP) dan akta kelahiran pada kantor Kecamatan Sangatta Kabupaten Kutai Timur.

\subsection{Variabel Penelitian dan Indikator}

Variabel penelitian adalah segala sesuatu yang berbentuk apa saja yang ditetapkan oleh peneliti untuk dipelajari sehingga diperoleh informasi tentang hal tersebut, kemudian ditarik kesimpulan" (Sugiyono, 2010:58). Variabel dalam penelitian ini dibedakan menjadi 2 (dua) yaitu variabel bebas (independent) dan variabel terikat (dependent). Adapun variabelvariabel dalam penelitian ini adalah :

Dalam menganalisis data penelitian ini menggunakan bantuan komputerisasi berupa program SPSS for Windows. Dan analisis data yang digunakan adalah dengan cara teknik kuantitatif, dimana data yang didapatkan telah diberi skor sesuai dengan skala pengukuran yang telah ditetapkan, kemudian menggunkan rumus matematis. Adapun dalam penelitian ini, metode analisis yang bisa digunakan adalah sebagai berikut:

\section{Uji Data}

Sebelum instrumen digunakan untuk menjaring data di lapangan maka terlebih dahulu perlu dilakukan uji validitas dan reabilitas. Sebagai berikut:

a) Uji Validitas

Validitas menurut Suharsimi adalah suatu ukuran yang menunjukkan kevalidan atau kesahihan sesuatu instrumen. (Arikunto, Suharsimi, 2002;144). Untuk menguji validitas instrumen dilakukan dengan cara mengoreksi skor jawaban yang telahdiperoleh dari setiap item dengan skor total dari keseluruhan item instrumen, dan semua diatas angka kritis.

Adapaun nilai angka kritisnya pada tingkat signifikan 5\% jika koefisien korelasi lebih besar dari nilai kritis maka alat ukur tersebut dikatakan valid. Dan rumus validitas yang digunakan dalam hal ini adalah "Korelasi Product Moment", (Arikunto, 
Suharsimi, 2002;146). dengan rumus:

$r x y=\frac{n \sum x y-\left(\sum x\right)\left(\sum y\right)}{\sqrt{\left\{n \sum x^{2}-(\Sigma x)^{2}\right\}\left\{n \sum y^{2}-(\Sigma y)^{2}\right\}}}$

Keterangan :

Rxy $=$ Koefesien korelasi

$\mathrm{n}=$ Jumlah responden

$\sum \mathrm{x}=$ Jumlah skor $\mathrm{X}$

$\sum \mathrm{y}=$ Jumlah skor $\mathrm{Y}$

$\sum_{\mathrm{Y}} \mathrm{xy}=$ Jumlah hasil perkalian antara skor $\mathrm{X}$ dan skor

Di sini cara yang sederhana dan mudah untuk memberikan penilaian apakah instrumen tersebut valid atau tidak. Yaitu dengan menggunakan interpretasi terhadap koefisien korelasi yang diperoleh, atau nilai r. Interpretasi tersebut adalah sebagai berikut:

Tabel 3.1 Interpretasi nilai $\mathbf{r}$

\begin{tabular}{|c|l|}
\hline Besarnya nilai $\mathbf{r}$ & Interpretasi \\
\hline Antara 0,800 sampai dengan 1,00 & Tinggi \\
\hline Antara 0,600 sampai dengan 0,800 & Cukup \\
\hline Antara 0,400 sampai dengan 0,600 & Agak rendah \\
\hline Antara 0,200 sampai dengan 0,400 & Rendah \\
\hline Antara 0,000 sampai dengan 0,200 & $\begin{array}{l}\text { Sangat rendah (tak } \\
\text { berkorelasi) }\end{array}$ \\
\hline
\end{tabular}

Sumber: Suharsimi Arikunto (2002:245)

b) Uji Reliabilitas

Reliabilitas adalah suatu instrumen yang cukup dapat dipercaya untuk digunakan sebagai alat pengumpul data karena instrumen tersebut sudah baik. Instrumen yang sudah dapat dipercaya, yang reliabel akan menghasilkan data yang dapat dipercaya juga. Untuk menguji tingkat reliabilitas instrumen, maka perlu digunakan reliabilitas internal yaitu dengan cara menganalisis data dari satu kali pengesetan. Dengan menggunakan rumus "Alpha" (Sugiono, 2006;211).

$r_{11}=\left(\frac{k}{k-1}\right)\left(\frac{\sigma_{b 2}^{2}}{\sigma_{1}^{2}}\right)$ 


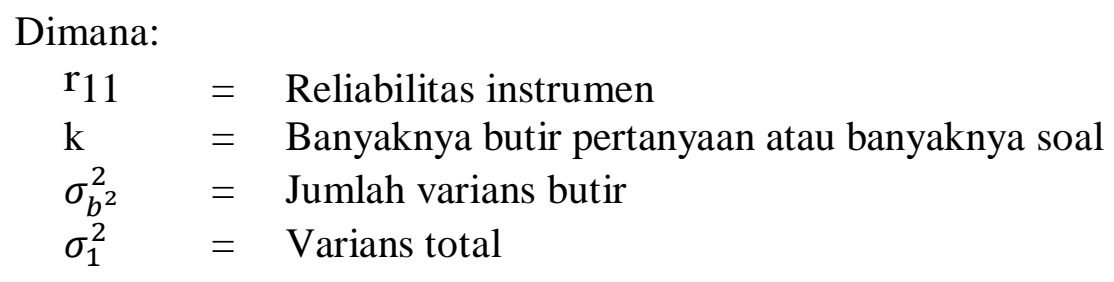

\section{Teknik Korelasi Regresi}

Metode ini digunakan peneliti dengan cara analisis regresi berganda yaitu suatu teknik yang analisis data dalam membahas hubungan antar variabel terikat dengan dua atau lebih variabel bebas. (Sugiono, 2006;211). Adapun model matematis dari korelasi regresi ini adalah sebagai berikut:

$\mathrm{Y}=\mathrm{a}+\mathrm{b}_{1} \mathrm{X}_{1}$

Dimana:

$$
\begin{aligned}
& \mathrm{a}=\text { Konstanta } \\
& \mathrm{Y}=\text { Variabel terikat } \\
& \mathrm{X}=\text { Varibel bebas } \\
& \mathrm{b} 1=\text { Koefisien Regresi }
\end{aligned}
$$

\section{Pengujian Koefisien Persamaan Regresi}

Dan dalam pembuktian hipotesis terhadap model maka perlu digunakan Uji t (Uji parsial) dimana digunakan untuk mengetahui pengaruh tiap-tiap variabel bebas terhadap variabel terikat. Uji ini dilakukan dengan cara membandingkan nilai t- ${ }_{\text {hitung }}$ dengan nilai ttabel. Jika ${ }^{-}{ }_{\text {hitung }}>\mathrm{t}_{\text {tabel }}$, Ha diterima atau menolak Ho. Artinya secara parsial variabel bebas berpengaruh nyata terhadap variabel tergantung pada tingkat kesalahan a = 0,5. (Gujarati, D dan Zain S, 2000;110).

Sedangkan data-data yang diperoleh dari lokasi penelitian selanjutnya diolah dengan menggunakan teknik analisis data secara kuantitatif dengan menggunakan skala likert. Berdasarkan fakta atau kejadian di lapangan, skala likert digunakan untuk menjabarkan indikator variabel dari variabel yang akan diukur, kemudian indikator tersebut dijadikan titik tolak untuk menyusun bagian-bagian instrument yang dapat berupa pertanyaan dan pernyataan.

Jawaban dari setiap bagian instrument yang menggunakan skala likert mempunyai pertanyaan yang diajukan kepada responden diberi gradasi dari sangat setuju/selalu/sangat positif, setuju/sering/positif, ragu-ragu/kadang-kadang/netral, tidak setuju/hampir tidak pernah/negative, sangat tidak setuju/tidak pernah atau gradasi lain yang disesuaikan dengan pertanyaan kuesioner yang diajukan. 
Pemberian skor dimulai dari skor tertinggi dengan skor 5 hingga terendah dengan skor 1 . Klasifikasi sebutan dengan kategori tersebut sebagai berikut:

1. Sangat setuju/selalu/sangat positif diberi skor

2. Setuju/sering/positif diberi skor

3. Ragu-ragu/kadang-kadang/netral diberi skor

4. Tidak setuju/hampir tidak pernah/negative diberi skor

5. Sangat tidak setuju/tidak pernah diberi skor

Selanjutnya untuk mengetahui kualitas pelayanan kesehatan puskesmas Sangkulirang dapat diklasifikasikan kedalam empat kelompok :
1. Sangat baik
skor $81 \%-100 \%$
2. Baik
skor $\quad 61 \%-80 \%$
3. Cukup baik
skor $41 \%-60 \%$
4. Tidak baik
skor $21 \%-40 \%$
5. Sangat Tidak Baik
skor $0 \%-20 \%$

Selain itu dalam menganalisis data-data, digunakan analisis rata-rata untuk mengetahui rata-rata jawaban responden pada setiap kategori pertanyaan dengan bantuan tabel frekuensi dan analisis persentase (Singarimbun dan Effendy, 1995). Dengan rumus :

$$
\mathrm{X}=\frac{\sum(\mathrm{F} \cdot \mathrm{X})}{\mathrm{N}}
$$

$$
\begin{aligned}
& \text { Dimana: } \mathrm{X}=\text { Rata-rata } \\
& \begin{array}{ll}
\sum_{\mathrm{N}}(\mathrm{F} . \mathrm{X}) & =\text { Jumlah skor kategori jawaban } \\
& =\text { Banyaknya responden }
\end{array} \\
& \text { Rata-rata skor } \\
& \text { Rata-rata persen }=\frac{}{\text { Banyaknya klasifikasi jawaban }} \times 100
\end{aligned}
$$

\section{HASIL PENELITIAN DAN PEMBAHASAN}

\section{A. Karakteristik Responden}

Adapun data yang diolah dalam penelitian ini adalah data tentang pengaruh kompetensi, terhadap kualitas pelayanan publik pada kantor camat sangatta selatan kabupaten kutai timur. Responden dalam penelitian ini adalah seluruh warga masyarakat yang melakukan pengurusan pembuatan KK, KTP dan Akte Kelahiran dikantor camat sangatta selatan kabupaten 
kutai timur yang berjumlah 53 orang. Dari hasil penelitian telah terkumpul sejumlah data yang diperlukan, data identitas responden, dan tanggapan responden tentang variabel kompetensi, budaya kerja, kepuasan kerja dan kinerja pegawai.

Tabel 4.6 Karakteristik Responden Berdasarkan Usia

\begin{tabular}{|c|c|c|c|}
\hline No & Usia (Tahun) & Jumlah & $(\boldsymbol{\%})$ \\
\hline 1 & $<20$ & 12 & 22.6 \\
\hline 2 & $21-30$ & 16 & 30.2 \\
\hline 3 & $31-40$ & 13 & 24.5 \\
\hline 4 & $41-50$ & 8 & 15.2 \\
\hline 5 & $>51$ & 4 & 7.5 \\
\hline \multicolumn{2}{|c|}{ Jumlah } & $\mathbf{5 3}$ & $\mathbf{1 0 0}$ \\
\hline
\end{tabular}

Sumber : Data diolah hasil penelitian

Dari tabel diatas menunjukkan bahwa usia responden yang menjadi responden paling dominan adalah yanag berusia antara 21-30 tahun sebanyak 16 orang/responden atau $30.2 \%$, dan yang berusia antara 31-40 tahun sebanyak 13 orang/responden atau $24.5 \%$. Disamping itu responden yang berusia $<20$ tahun sebanyak 12 orang/responden atau $22.6 \%$, dan responden yang berusia antara 41-50 tahun sebanyak 8 orang/ responden atau $15.2 \%$, serta responden yang berusia $>51$ tahun berjumlah 4 orang/responden atau $7.5 \%$.

Hal ini mengindikasikan bahwa berdasarkan tingkat usia, responden yang melakukan pengurusan KK, KTP dan AK di kantor camat sangatta selatan kabupaten kutai timur sangat variatif.

1. Karakteristik responden jenis kelamin

Tabel 4.7 Karakteristik Responden Berdasarkan Jenis Kelamin

\begin{tabular}{|l|l|c|c|}
\hline No & Jenis Kelamin & Jumlah & $(\boldsymbol{\%})$ \\
\hline 1 & Laki-laki & 37 & 69.8 \\
\hline 2 & Perempuan & 16 & 30.2 \\
\hline \multicolumn{2}{|c|}{ Jumlah } & $\mathbf{5 3}$ & $\mathbf{1 0 0}$ \\
\hline
\end{tabular}

Sumber : Data olahan hasil penelitian

Dari Tabel 4.7 di atas dapat dilihat Jenis Kelamin responden laki-laki sebanyak 37 orang/responnden atau $69.8 \%$ dan perempuan sebanyak 16 orang/responden atau 30.2\%. Hal ini menunjukkan bahwa yang paling banyak melakukan pengurusan KK, KTP dan AK pada kantor camat sangatta selatan kabupaten kutai timur adalah laki-laki dibandingkan perempuan. 
2. Karakteristik responden tingkat pendidikan

Tabel 4.8 : Karakteristik Responden Berdasarkan Tingkat Pendidikan

\begin{tabular}{|l|l|c|c|}
\hline No & Tingkat Pendidikan & Jumlah & $(\boldsymbol{\%})$ \\
\hline 1 & SD & - & - \\
\hline 2 & SLTP & 10 & 18.9 \\
\hline 3 & SLTA/Sederajat & 28 & 52.8 \\
\hline 4 & Diploma III & 12 & 22.6 \\
\hline 5 & Strata 1 (S1) & 3 & 5.7 \\
\hline 6 & Strata 2 (S2) & - & - \\
\hline \multicolumn{2}{|c|}{ Jumlah } & $\mathbf{5 3}$ & $\mathbf{1 0 0}$ \\
\hline
\end{tabular}

Sumber : Data olahan hasil penelitian

Dari tabel 4.8 diatas menunjukkan bahwa responden yang yang melakukan pengurusan administrasi di kantor camat sangatta selatan kabupaten kutai timur lebih didominasi yang memiliki latar belakang pandidikan SLTA/Sederajat sebanyak 28 orang/responden atau $52.8 \%$, sedangkan yang latar belakang Diploma III sebanyak 12 orang/ responden atau 22.6\%, disamping itu jumlah responden yang memiliki latar belakang SLTP sebanyak 10 orang/responden atau $18.9 \%$, dan yang memiliki latar belakang Strata 1 hanya 3 orang/responden atau 5.7\%.

Jika dilihat dari latar belakang pendidikan yang dimiliki responden yang melakukan pengurusan administrasi pada kantor camat sangatta selatan kabupaten kutai timur, didominasi oleh responden yang mempunyai latar belakang pendidikan SLTA

\section{B. Kompetensi Aparatur Pemerintah (variabe $X$ )}

Adapun data yang diolah dalam penelitian ini adalah data tentang pengaruh kompetensi terhadap kualitas pelayanan publik pada kantor camat sangatta selatan kabupaten kutai timur. Responden dalam penelitian ini adalah masyarakat yang melakukan pengurusan administrasi di kantor camat sangatta selatan kabupaten kutai timur yang berjumlah 53 orang/responden.

Dari hasil penelitian telah terkumpul sejumlah data yang diperlukan, data identitas responden, dan tanggapan responden tentang variabel kompetensi, maka diperoleh data sebagai berikut : 
Tabel 4.9 Pengawasan Pimpinan

\begin{tabular}{|c|c|c|c|c|c|}
\hline \multirow{2}{*}{ NO } & \multirow{2}{*}{ Pertanyaan } & \multicolumn{4}{|c|}{ Jawaban responden } \\
\hline & & SS & $\mathrm{S}$ & TS & STS \\
\hline 1 & $\begin{array}{l}\text { Pegawai kecamatan mengetahui } \\
\text { tugas dan tanggung jawabnya } \\
\text { dalam menyelesaikan pekerjaan }\end{array}$ & $\begin{array}{c}12 \\
22.6 \%\end{array}$ & $\begin{array}{r}36 \\
67.9 \%\end{array}$ & $\begin{array}{c}5 \\
9.4 \%\end{array}$ & - \\
\hline 2 & $\begin{array}{l}\text { Pegawai kecamatan mengetahui } \\
\text { cara mengoperasikan komputer } \\
\text { dengan baik dan benar }\end{array}$ & $\begin{array}{c}13 \\
24.5 \%\end{array}$ & $\begin{array}{c}40 \\
75.5 \%\end{array}$ & - & - \\
\hline 3 & $\begin{array}{l}\text { Pegawai kecamatan dapat } \\
\text { mengatasi keluhan pengunjung } \\
\text { terkait dengan pembuatan } \\
\text { admistrasi KK, KTP, AK }\end{array}$ & $\begin{array}{r}9 \\
17 \%\end{array}$ & $\begin{array}{r}42 \\
79.2 \%\end{array}$ & $\begin{array}{r}2 \\
3.8 \%\end{array}$ & - \\
\hline 4 & $\begin{array}{l}\text { Pegawai kecamatan selalu } \\
\text { memahami keinginan } \\
\text { pengunjung kantor kecamatan }\end{array}$ & $\begin{array}{r}15 \\
28.3 \%\end{array}$ & $\begin{array}{r}36 \\
67.9 \%\end{array}$ & $\begin{array}{r}2 \\
3.8 \%\end{array}$ & - \\
\hline 5 & $\begin{array}{l}\text { Pegawai kecamatan memiliki } \\
\text { pemahaman yang baik mengenai } \\
\text { proses pembuat KK. KTP dan } \\
\text { AK }\end{array}$ & $\begin{array}{r}15 \\
28.3 \%\end{array}$ & $\begin{array}{r}38 \\
71.7 \%\end{array}$ & - & - \\
\hline 6 & $\begin{array}{l}\text { Pegawai kecamatan memahami } \\
\text { tata cara melakukan pelayanan } \\
\text { dengan baik }\end{array}$ & $\begin{array}{r}9 \\
17 \%\end{array}$ & $\begin{array}{r}42 \\
79.2 \%\end{array}$ & $\begin{array}{r}2 \\
3.8 \%\end{array}$ & - \\
\hline 7 & $\begin{array}{l}\text { Pegawai kecamatan memiliki } \\
\text { ketrampilan yang bagus dalam } \\
\text { menyelesaikan pekerjaan }\end{array}$ & $\begin{array}{r}19 \\
35.8 \%\end{array}$ & $\begin{array}{r}34 \\
64.2 \%\end{array}$ & - & - \\
\hline 8 & $\begin{array}{l}\text { Pegawai kecamatan memiliki } \\
\text { kemampuan yang baik dalam } \\
\text { menyelesaikan pekerjaan }\end{array}$ & $\begin{array}{r}16 \\
30.2 \%\end{array}$ & $\begin{array}{r}32 \\
60.3 \%\end{array}$ & $\begin{array}{r}5 \\
9.4 \%\end{array}$ & - \\
\hline 9 & $\begin{array}{l}\text { Pegawai kecamatan memiliki } \\
\text { kemampuan dalam } \\
\text { menyelesaikan pekerjaan dengan } \\
\text { cepat }\end{array}$ & $\begin{array}{r}9 \\
17 \%\end{array}$ & $\begin{array}{r}42 \\
79.2 \%\end{array}$ & $\begin{array}{r}2 \\
3.8 \%\end{array}$ & - \\
\hline 10 & $\begin{array}{l}\text { Pelayanan yang diberikan } \\
\text { pegawai kecamatan terasa } \\
\text { menyenangkan }\end{array}$ & $\begin{array}{r}30 \\
56.6 \%\end{array}$ & $\begin{array}{r}23 \\
43.4 \%\end{array}$ & - & - \\
\hline 11 & $\begin{array}{l}\text { Pegawai kecamatan bersikap } \\
\text { jujur dalam memberikan } \\
\text { pelayanan }\end{array}$ & $\begin{array}{r}28 \\
52.8 \%\end{array}$ & $\begin{array}{r}25 \\
47.2 \%\end{array}$ & $\begin{array}{lll}- & \text { r }\end{array}$ & - \\
\hline
\end{tabular}




\begin{tabular}{|c|c|c|c|c|c|}
\hline 12 & $\begin{array}{l}\text { Pegawai kecamatan tidak } \\
\text { bersikap diskriminasi } \\
\text { (membeda-bedakan) saat } \\
\text { memberikan pelayanan }\end{array}$ & $\begin{array}{c}12 \\
22.6 \%\end{array}$ & $\begin{array}{c}36 \\
67.9 \%\end{array}$ & $\begin{array}{c}5 \\
9.4 \%\end{array}$ & - \\
\hline 13 & $\begin{array}{l}\text { Pegawai kecamatan selalu } \\
\text { memberikan senyum sapa setiap } \\
\text { kali akan memberikan pelayanan }\end{array}$ & $\begin{array}{c}13 \\
24.5 \%\end{array}$ & $\begin{array}{c}40 \\
75.5 \%\end{array}$ & - & - \\
\hline 14 & $\begin{array}{l}\text { Dalam melayani masyarakat } \\
\text { pegawai kecamatan bersikap } \\
\text { sopan dan santun. }\end{array}$ & $\begin{array}{r}9 \\
17 \%\end{array}$ & $\begin{array}{r}42 \\
79.2 \%\end{array}$ & $\begin{array}{r}2 \\
3.8 \%\end{array}$ & - \\
\hline 15 & $\begin{array}{l}\text { Pegawai kecamatan tidak } \\
\text { melibatkan masalah pribadi saat } \\
\text { mem-berikan pelayanan }\end{array}$ & $\begin{array}{r}15 \\
28.3 \%\end{array}$ & $\begin{array}{c}36 \\
67.9 \%\end{array}$ & $\begin{array}{r}2 \\
3.8 \%\end{array}$ & - \\
\hline 16 & $\begin{array}{l}\text { Pegawai kecamatan memberikan } \\
\text { informasi yang jelas tentang alur } \\
\text { pengurusan Kartu Keluarga } \\
\text { (secara langsung) kepada } \\
\text { pengunjung }\end{array}$ & $\begin{array}{r}15 \\
28.3 \%\end{array}$ & $\begin{array}{r}38 \\
71.7 \%\end{array}$ & - & - \\
\hline 17 & $\begin{array}{l}\text { Pegawai mempunyai minat yang } \\
\text { tinggi dalam melayani } \\
\text { masyarakat }\end{array}$ & $\begin{array}{r}9 \\
17 \%\end{array}$ & $\begin{array}{r}42 \\
79.2 \%\end{array}$ & $\begin{array}{r}2 \\
3.8 \%\end{array}$ & - \\
\hline 18 & $\begin{array}{l}\text { Pegawai cenderung mengerjakan } \\
\text { tugas yang dikuasai saja }\end{array}$ & $\begin{array}{r}19 \\
35.8 \%\end{array}$ & $\begin{array}{r}34 \\
64.2 \%\end{array}$ & & - \\
\hline 19 & $\begin{array}{l}\text { Semua pegawai kecamatan } \\
\text { terlihat menyukai pekerjaanya }\end{array}$ & $\begin{array}{r}16 \\
30.2 \%\end{array}$ & $\begin{array}{r}32 \\
60.3 \%\end{array}$ & $\begin{array}{r}5 \\
9.4 \%\end{array}$ & \\
\hline
\end{tabular}

\section{Sumber : Data yang diolah dari kuesioner}

Dari hasil tabel 4.9 diatas maka dapat dijelaskan sebagai berikut bahwa responden menjawab terbanyak yang dimulai dari pertanyaan 1 yaitu sangat setuju dengan jumlah 36 responden atau $67.9 \%$, untuk pertanyaan 2 yaitu setuju dengan jumlah 40 responden atau $75.5 \%$, untuk pertanyaan 3 yaitu setuju dengan jumlah 42 responden atau $79.2 \%$, untuk pertanyaan 4 yaitu setuju dengan jumlah 36 atau $67.9 \%$, untuk pertanyaan 5 yaitu setuju dengan jumlah 38 atau 71\%, untuk pertanyaan 6 yaitu tidak setuju dengan jumlah 42 atau $79.2 \%$, untuk pertanyaan 7 yaitu sangat setuju dan setuju yang masing-masing dengan jumlah 34 atau $64.2 \%$, untuk Pertanyaan 8 yaitu setuju dengan jumlah 32 atau $60.3 \%$. Untuk pertanyaan 9 yaitu sangat setuju dengan jumlah 42 
responden arau $79.2 \%$, untuk pertanyaan 10 yaitu sangat setuju dengan jumlah 30 responden atau $56.6 \%$.

Untuk pertanyaan 11 yaitu sangat setuju dengan jumlah 28 responden atau $52.8 \%$, untuk pertanyaan 12 yaitu setuju dengan jumlah 36 responden atau $67.9 \%$, untuk pertanyaan 13 yaitu setuju dengan jumlah 40 atau $75.5 \%$, untuk pertanyaan 14 yaitu setuju dengan jumlah 42 atau $79.2 \%$, untuk pertanyaan 15 yaitu setuju dengan jumlah 36 atau $67.9 \%$, untuk pertanyaan 16 yaitu setuju dan setuju yang masing-masing dengan jumlah 38 atau $71.7 \%$, untuk Pertanyaan 17 yaitu setuju dengan jumlah 42 atau 79.2\%. Untuk pertanyaan 18 yaitu setuju dengan jumlah 34 responden arau $64.2 \%$, untuk pertanyaan 19 yaitu sangat setuju dengan jumlah 34 responden atau 64.2\%. Dengan demikian diketahui bahwa pegawai rata-rata menjawab dengan setuju.

\section{Kualitas Pelayanan Publik (variabel Y)}

Selanjutnya peneliti akan mendeskripsikan data dari hasil observasi yang dilakukan melalui penyebaran angket kepada pegawai Kantor Dinas Pendapatan Daerah masyarakat yang melakukan penngurusan administrasi di kecamatan sangata selatan kabupaten kutai timur. Hal ini bertujuan untuk mengetahui bagaimana kualitas pelayanan publik di kecamatan sangatta selatan kabupaten kutai timur yang selama ini di upayakan oleh segenap pegawai.

Untuk lebih lengkapnya peneliti mengurainya dalam bentuk tabel disertai dengan pemaparan dan kesimpulan hasil jawaban dari pernyataan yang diajukan melalui angket sebagai berikut :

\section{Tabel 4.10 Disiplin pegawai Pegawai}

\begin{tabular}{|l|l|r|r|r|c|}
\hline \multirow{2}{*}{ NO } & \multicolumn{2}{|c|}{ Pertanyaan } & \multicolumn{4}{|c|}{ Jawaban responden } \\
\cline { 3 - 6 } & & \multicolumn{1}{|c|}{1} & \multicolumn{1}{c|}{3} & 4 \\
\hline \multirow{2}{*}{1} & $\begin{array}{l}\text { Kebersihan ruang Kantor } \\
\text { Kecamatan terjaga dengan baik }\end{array}$ & 9 & 42 & 2 & - \\
\hline \multirow{2}{*}{2} & $\begin{array}{l}\text { Kebersihan halaman kantor } \\
\text { Kecamatan terjaga dengan baik. }\end{array}$ & $35.8 \%$ & $64.2 \%$ & $3.8 \%$ & - \\
\hline 3 & $\begin{array}{l}\text { Ruang tunggu tamu kantor } \\
\text { Kecamatan Mirit nyaman }\end{array}$ & $30.2 \%$ & $60.3 \%$ & $9.4 \%$ & - \\
\hline
\end{tabular}




\begin{tabular}{|c|c|c|c|c|c|}
\hline 4 & $\begin{array}{l}\text { Fasilitas yang di tawarkan } \\
\text { oleh kantor Kecamatan Mirit } \\
\text { lengkap sesuai dengan } \\
\text { harapan pengujung }\end{array}$ & $\begin{array}{r}9 \\
17 \%\end{array}$ & $\begin{array}{r}42 \\
79.2 \%\end{array}$ & $\begin{array}{r}2 \\
3.8 \%\end{array}$ & - \\
\hline 5 & $\begin{array}{l}\text { Pegawai kecamatan bertindak } \\
\text { cepat dalam melayani } \\
\text { pengunjung yang datang ke } \\
\text { kantor kecamatan. }\end{array}$ & $\begin{array}{r}30 \\
56.6\end{array}$ & $\begin{array}{r}23 \\
43.4 \%\end{array}$ & - & - \\
\hline 6 & $\begin{array}{l}\text { Prosedur pelayanan pembuatan } \\
\text { KK tidak berbelit - belit }\end{array}$ & $\begin{array}{r}5 \\
11.9 \% \\
\end{array}$ & $\begin{array}{r}25 \\
59.5 \% \\
\end{array}$ & $\begin{array}{r}12 \\
28.6 \\
\end{array}$ & - \\
\hline 7 & $\begin{array}{l}\text { Pelayanan yang diberikan oleh } \\
\text { pegawai } \\
\text { kecamatan sudah sesuai harapan } \\
\text { / memuaskan }\end{array}$ & $\begin{array}{c}12 \\
22.6 \%\end{array}$ & $\begin{array}{c}36 \\
67.9 \%\end{array}$ & $\begin{array}{c}5 \\
9.4 \%\end{array}$ & - \\
\hline 8 & $\begin{array}{l}\text { Pegawai kecamatan tidak } \\
\text { membiarkan pengunjung } \\
\text { menunggu lama tanpa ada suatu } \\
\text { alasan yang jelas }\end{array}$ & $\begin{array}{c}13 \\
24.5 \%\end{array}$ & $\begin{array}{c}40 \\
75.5 \%\end{array}$ & - & - \\
\hline 9 & $\begin{array}{l}\text { Pegawai kecamatan selalu siap } \\
\text { untuk membantu pengunjung } \\
\text { kantor kecamatan }\end{array}$ & $\begin{array}{r}9 \\
17 \%\end{array}$ & $\begin{array}{r}42 \\
79.2 \%\end{array}$ & $\begin{array}{r}2 \\
3.8 \%\end{array}$ & - \\
\hline 10 & $\begin{array}{l}\text { Pegawai kecamatan cepat dalam } \\
\text { menyelesaikan pekerjaan }\end{array}$ & $\begin{array}{r}15 \\
28.3 \% \\
\end{array}$ & $\begin{array}{c}36 \\
67.9 \% \\
\end{array}$ & $\begin{array}{r}2 \\
3.8 \%\end{array}$ & - \\
\hline 11 & $\begin{array}{l}\text { Pegawai kecamatan ramah dalam } \\
\text { melayani pengunjung }\end{array}$ & $\begin{array}{r}15 \\
28.3 \%\end{array}$ & $\begin{array}{r}38 \\
71.7 \%\end{array}$ & & - \\
\hline 12 & $\begin{array}{l}\text { Pegawai kecamatan selalu } \\
\text { memberikan senyum sapa } \\
\text { setiap kali akan memberikan } \\
\text { pelayanan. }\end{array}$ & $\begin{array}{r}9 \\
17 \%\end{array}$ & $\begin{array}{r}42 \\
79.2 \%\end{array}$ & $\begin{array}{r}2 \\
3.8 \%\end{array}$ & - \\
\hline 13 & $\begin{array}{l}\text { Pegawai kecamatan mempunyai } \\
\text { pengetahuan yang luas dalam } \\
\text { bidangnya }\end{array}$ & $\begin{array}{r}19 \\
35.8 \%\end{array}$ & $\begin{array}{r}34 \\
64.2 \%\end{array}$ & - & - \\
\hline 14 & $\begin{array}{l}\text { Pegawai kecamatan selalu } \\
\text { memberikan rasa nyaman kepada } \\
\text { masyarakat dalam melakukan } \\
\text { pelayanan. }\end{array}$ & $\begin{array}{r}9 \\
17 \%\end{array}$ & $\begin{array}{r}42 \\
79.2 \%\end{array}$ & $\begin{array}{r}2 \\
3.8 \%\end{array}$ & - \\
\hline 15 & $\begin{array}{l}\text { Pegawai kecamatan mengerti } \\
\text { keinginan pengunjung kantor } \\
\text { kecamatan Mirit }\end{array}$ & $\begin{array}{r}15 \\
28.3 \%\end{array}$ & $\begin{array}{c}36 \\
67.9 \%\end{array}$ & $\begin{array}{r}2 \\
3.8 \%\end{array}$ & - \\
\hline
\end{tabular}




\begin{tabular}{|l|l|r|r|r|c|}
\hline 16 & $\begin{array}{l}\text { Pegawai kecamatan } \\
\text { memberikan pelayanan kepada } \\
\text { pengunjung melalui komunikasi } \\
\text { (gaya bicara) yang baik }\end{array}$ & $28.3 \%$ & $31.7 \%$ & - & - \\
\hline
\end{tabular}

Sumber : Data yang diolah dari kuesioner

Dari hasil tabel 4.10 diatas maka dapat dijelaskan sebagai berikut bahwa responden menjawab terbanyak yang dimulai dari pertanyaan 1 yaitu jawaban setuju dengan jumlah 42 responden atau $79.2 \%$, untuk pertanyaan 2 yaitu jawaban setuju dengan jumlah 34 responden atau $64.2 \%$, untuk jawaban pertanyaan 3 yaitu setuju dengan jumlah 32 responden atau $60.2 \%$, untuk jawaban pertanyaan 4 yaitu jawaban setuju dengan jumlah 42 responden atau $79.2 \%$, untuk pertanyaan 5 yaitu jawaban sangat setuju dengan jumlah 30 responden atau 56.6\%, untuk pertanyaan 6 yaitu jawaban setuju dengan jumlah 25 responden atau $47.2 \%$, untuk pertanyaan 7 yaitu jawaban setuju dengan jumlah 36 responden atau $67.9 \%$, untuk pertanyaan 8 yaitu jawaban setuju dengan jumlah 40 responden atau $75.5 \%$, untuk pertanyaan 9 yaitu jawaban setuju dengan jumlah 42 responden atau $79.2 \%$, untuk pertanyaan 10 yaitu jawaban setuju dengan jumlah 36 responden atau $67.9 \%$, untuk pertanyaan 11 yaitu jawaban setuju dengan jumlah 38 responden atau $71.7 \%$, untuk pertanyaan 12 yaitu jawaban setuju dengan jumlah 42 responden atau $79.2 \%$, untuk pertanyaan 13 yaitu jawaban setuju dengan jumlah 34 responden atau $64.2 \%$, untuk pertanyaan 14 yaitu jawaban setuju dengan jumlah 42 responden atau $79.2 \%$, untuk pertanyaan 15 yaitu jawaban setuju dengan jumlah 36 responden atau $67.9 \%$, untuk pertanyaan 16 yaitu jawaban setuju dengan jumlah 38 responden atau $71.7 \%$, Dengan demikian diketahui bahwa pegawai rata-rata menjawab dengan setuju.

\section{Analisa Hasil Penelitian dan Pembahasan}

\section{Pengujian Validitas dan Realibitas}

\section{a. Uji Validitas}

Uji Validitas digunakan sebagai statu usuran yang menunjukkan tingkat revalidan atau kesahihan instrumen. Sebuah instrumen dikatakan valid apabila dapat mengungkap data dari variabel yang diteliti secara tepat. Tinggi rendahnya validitas menunjukkan sejauh mana data yang terkumpul tidak menyimpang dari gambaran tentang variabel yang dimaksud. 
Suatu instrumen yang valid memiliki validitas yang tinggi dan sebaliknya. (Arikunto, 2002:136). Uji validitas kesioner dilakukan pada setiap sub variabel yang dimana tiap sub variabel terdiri dari beberapa item pertanyaan. Pengukuran validitas dilakukan dengan analisis korelasi Produk Moment dengan kriteria pengambilan keputusan sebagai berikut :

1. Jika $r$ hitung $>r$ tabel maka kuesioner valid

2. Jika $r$ hitung $<r$ tabel maka kuesioner tidak valid

Untuk menentukan sebuah pertanyaan valid atau tidak, perlu diketahui $r$ hitung yang kemudian dibandingkan dengan $r$ tabel, dimana jumlah sampel sebanyak 42 orang responden, dengan tingkat signifikansi $95 \%$ didapat angka $r$ tabel sebesar 0,304. Dalam menguji validitas masing-masing sub variabel peneliti menggunakan teknik korelasi Pearson dengan bantuan SPSS 17. Seperti yang dapat dilihat hasil pengujian validitas untuk semua item pertanyaan dalam kuesioner adalah valid sehingga dapat digunakan untuk pengumpulan data.

Dengan bantuan program SPSS 17, didapatkan hasil uji validitas yang menunjukkan bahwa semua item pertanyaan yang mewakili variabel $\mathrm{X}$ berada pada tingkat signifikansi 0,05\%. Tingkat ignifikansi yang sama didapatkan pula setelah uji validitas dilakukan terhadap masing masing item pertanyaan yang mewakili variabel Y. Hasil perhitungan validitas untuk semua item pertanyaan dalam kuesioner dapat dilihat pada tabel 4.12 sebagai berikut :

Tabel 4.11 Hasil Pengujian Validitas Intrumen Penelitian

\begin{tabular}{|c|c|c|c|c|c|c|c|}
\hline No. & $\begin{array}{c}\mathbf{r} \\
\text { Tabel }\end{array}$ & $\begin{array}{c}\mathbf{r} \\
\text { Hitung }\end{array}$ & Ket. & No. & $\begin{array}{c}\mathbf{r} \\
\text { Tabel }\end{array}$ & $\begin{array}{c}\mathbf{r} \\
\text { Hitung }\end{array}$ & Ket. \\
\hline 1. & 0.270 & 0,351 & Valid & 1. & 0.270 & 0.516 & Valid \\
\hline 2. & 0.270 & 0,581 & Valid & 2. & 0.270 & 0.464 & Valid \\
\hline 3. & 0.270 & 0,405 & Valid & 3. & 0.270 & 0.443 & Valid \\
\hline 4. & 0.270 & 0,366 & Valid & 4. & 0.270 & 0.430 & Valid \\
\hline 5. & 0.270 & 0,525 & Valid & 5. & 0.270 & 0.465 & Valid \\
\hline 6. & 0.270 & 0,464 & Valid & 6. & 0.270 & 0.283 & Valid \\
\hline 7. & 0.270 & 0,476 & Valid & 7. & 0.270 & 0.357 & Valid \\
\hline 8. & 0.270 & 0,442 & Valid & 8. & 0.270 & 0.306 & Valid \\
\hline 9. & 0.270 & 0,411 & Valid & 9. & 0.270 & 0.318 & Valid \\
\hline 10. & 0.270 & 0,469 & Valid & 10. & 0.270 & 0.434 & Valid \\
\hline 11. & 0.270 & 0,405 & Valid & 11. & 0.270 & 0.340 & Valid \\
\hline 12 & 0.270 & 0,527 & Valid & 12. & 0.270 & 0.390 & Valid \\
\hline 13 & 0.270 & 0,641 & Valid & 13. & 0.270 & 0.283 & Valid \\
\hline
\end{tabular}




\begin{tabular}{|l|l|l|l|l|l|l|l|}
\hline 14 & 0.270 & 0,636 & Valid & 14 & 0.270 & 0.357 & Valid \\
\hline 15 & 0.270 & 0,377 & Valid & 15 & 0.270 & 0.306 & Valid \\
\hline 16 & 0.270 & 0,305 & Valid & 16 & 0.270 & 0.448 & Valid \\
\hline 17 & 0.270 & 0.476 & Valid & \multicolumn{1}{|l|}{} \\
\hline 18 & 0.270 & 0.377 & Valid & \multicolumn{1}{|l|}{} \\
\hline 19 & 0.270 & 0.479 & Valid & \multicolumn{1}{|l}{} \\
\hline
\end{tabular}

Sumber : Data yag dioleh 2018

Berdasarkan tabel diatas dapat diketahui bahwa semua item pertanyaan adalah valid. Hal ini dapat dilihat dari semua item pertanyaan yang memiliki nilai $r$ hitung lebih besar dari $r$ tabel, maka kuesioner dinyatakan valid. Karena semua item valid maka semua pertanyaan dapat digunakan dalam penyebaran kuesioner untuk pengambilan data.

\section{b. Uji Realibilitas}

Uji Reabilitas dalam penelitian ini menggunakan rumus Alpha Cronbach dengan bantuan program SPSS 17. Peneliti melakukan uji reabilitas terhadap masing-masing instrumen variabel $\mathrm{X}$ dan $\mathrm{Y}$ dari 42 kuesioner yang disebar kepada responden. Koefisien reliabilitas ditunjukkan oleh Alpha Cronbach, semakin besar nilai alphanya, maka semakin tinggi reliabilitasnya dan sebaliknya. Selanjutnya indeks reliabilitas diinterpretasikan dengan menggunakan interpretasi $r$ untuk menyimpulkan bahwa alat ukur yang digunakan cukup atau tidak reliabel. Nilai interpretasi reliabilitas $\mathrm{r}$ tabel 0.270 , dilakukan uji reabilitas terhadap variabel $\mathrm{X}$ dan $\mathrm{Y}$ dengan bantuan SPSS 17, didapat hasil sebagai berkut :

Tabel 4.12 Hasil Pengujian Reabilitas

\begin{tabular}{|l|c|c|l|c|c|}
\hline Variabel & $\begin{array}{c}\text { Alpha } \\
(\mathbf{r} \\
\text { hitung) }\end{array}$ & Ket. & Variabel & $\begin{array}{c}\text { Alpha } \\
(\mathbf{r} \\
\text { hitung })\end{array}$ & Ket. \\
\hline Item 1 & 0.562 & Reliabel & Item 1 & 0.411 & Reliabel \\
\hline Item 2 & 0.606 & Reliabel & Item 2 & 0.558 & Reliabel \\
\hline Item 3 & 0.539 & Reliabel & Item 3 & 0.433 & Reliabel \\
\hline Item 4 & 0.545 & Reliabel & Item 4 & 0.445 & Reliabel \\
\hline Item 5 & 0.581 & Reliabel & Item 5 & 0.424 & Reliabel \\
\hline Item 6 & 0.529 & Reliabel & Item 6 & 0.466 & Reliabel \\
\hline Item 7 & 0.570 & Reliabel & Item 7 & 0.453 & Reliabel \\
\hline Item 8 & 0.535 & Reliabel & Item 8 & 0.472 & Reliabel \\
\hline
\end{tabular}




\begin{tabular}{|l|l|l|l|l|l|}
\hline Item 9 & 0.567 & Reliabel & Item 9 & 0.463 & Reliabel \\
\hline Item 10 & 0.580 & Reliabel & Item 10 & 0.430 & Reliabel \\
\hline Item 11 & 0.602 & Reliabel & Item 11 & 0.451 & Reliabel \\
\hline Item 12 & 0.515 & Reliabel & Item 12 & 0.442 & Reliabel \\
\hline Item 13 & 0.498 & Reliabel & Item 13 & 0.466 & Reliabel \\
\hline Item 14 & 0.500 & Reliabel & Item 14 & 0.453 & Reliabel \\
\hline Item 15 & 0.560 & Reliabel & Item 15 & 0.472 & Reliabel \\
\hline Item 16 & 0.552 & Reliabel & Item 16 & 0.444 & Reliabel \\
\hline Item 17 & 0.527 & Reliabel & & & \\
\hline Item 18 & 0.542 & Reliabel & & & \\
\hline Item 19 & 0.530 & Reliabel & & & \\
\hline
\end{tabular}

Sumber: Data yang diolah, 2018

Hasil perhitungan yang tertera pada tabel 4.13 diatas menunjukkan bahwa data yang terkumpul adalah reliabel. Oleh karena berdasarkan uji coba instrumen ini sudah valid dan reliabel seluruh item pertanyaannya, maka item pertanyaan ini dapat digunakan untuk pengukuran dalam rangka pengumpulan data.

\section{Analisis Regresi Linier Sederhana}

Analisis regresi linear sederhan digunakan untuk mengetahui besarnya pengaruh variabel bebas kompetensi aparatur pemerintah terhadap variabel kualitas pelayanan publik. Untuk membuktikan hipotesis yang telah diajukan, maka dapat dilihat pada hasil perhitungan regresi dengan menggunkaan SPSS 17 coefficient. Berdasarkan hasil perhitungan regresi linear sederhana dapat dilihat pada tabel berikut ini :

Tabel 4.13 Hasil Perhitungan Regresi Linear sederhana dengan menggunakan program SPSS ver. 17.

Coefficients $_{\mathrm{a}}$

\begin{tabular}{|l|r|r|r|r|c|}
\hline \multirow{2}{*}{ Model } & \multicolumn{2}{|c|}{$\begin{array}{c}\text { Unstandardized Coef f } \\
\text { icients }\end{array}$} & $\begin{array}{l}\text { Standardized } \\
\text { Coef f icients }\end{array}$ & & \\
\cline { 2 - 5 } & $\mathrm{B}$ & $\begin{array}{l}\text { Std. } \\
\text { Error }\end{array}$ & Beta & $\mathrm{T}$ & Sig. \\
\hline $\begin{array}{l}\text { (Constant) } \\
\begin{array}{l}\text { Kompetensi aparatur } \\
\text { pemerintah }\end{array}\end{array}$ & 32.433 & 6.291 & & 5.156 & .000 \\
\hline
\end{tabular}

a. Dependent Variabel : kualitas pelayanan publik 
Dari tabel perhitungan dengan menggunakan program SPSS for windows ver. 17 tersebut diatas, maka diperoleh persamaan regresi berganda sebagai berikut :

$\mathrm{Y}=32.433+0,324 \mathrm{x}$

Persamaan regresi linier sederhana tersebut dapat dijelaskan sebagai berikut :

a. Konstanta sebesar 32.433; artinya jika tidak ada semua variabel independen kompetensi aparatur pemerintah (X) maka kualitas pelayana publik (Y) nilainya adalah 32.433 .

b. Koefisien regresi variabel kompetensi aparatur pemerintah (X) sebesar 0,324 ; artinya jika variabel independen lain nilainya 0 dan kompetensi aparatur pemerintah mengalami kenaikan 1 satuan, maka kualitas pelayanan publik (Y) akan mengalami peningkatkan sebesar 0,324. Koefisien bernilai positif artinya terjadi hubungan positif antara kompetensi aparatur pemerintah dengan kualitas pelayan publik, yaitu semakin tinggi kompetensi aparatur pemerintah maka semakin baik kualitas pelayanan pabliknya.

\section{Uji Hipotesis}

\section{a. $\mathbf{U j i} \mathbf{R}^{2}$}

Tabel 4.14 koefisiensi determinasi model summary

Model Summary

\begin{tabular}{|c|c|r|r|r|}
\hline Model & R & R Square & $\begin{array}{c}\text { Adjusted R } \\
\text { Square }\end{array}$ & $\begin{array}{c}\text { Std. Error of } \\
\text { the Estimate }\end{array}$ \\
\hline 1 & $.820 \mathrm{a}$ & .776 & .460 & 6.484 \\
\hline
\end{tabular}

a. Predictors ; (Constant), Pengawasa Pimpinan

Berdasarkan hasil uji model summary didapat angka $\mathrm{R}$ sebesar 0,820. Berdasarkan pedoman interpretasi koefisien korelasi yang telah disajikan pada tabel 4.15 diatas, angka ini menunjukkan bahwa korelasi atau hubungan antara kualitas pelayanan publik dengan variabel independen (kompetense apartur pemerintah) adalah sangat kuat. Angka R Square atau koefisien determinasi $\left(\mathrm{R}^{2}\right)$ adalah 0,776 hal ini berarti $77.6 \%$. Sedangkan sisanya sebesar $22.4 \%$ dipengaruhi atau dijelaskan oleh variabel lain yang tidak dimasukkan dalam model penelitian ini. 


\section{b. Uji t}

Pengujian hipotesis dengan menggunakan uji t dengan memasukkan nilai hasil perhitungan regresi linear sederhana ke dalam uji t. Berdasarkan hasil perhitungan melalui uji t, maka diperoleh hasil sebagai berikut :

Tabel 4.15 Coefficients $\mathrm{t}$ hitung dengan program SPSS for windows ver. 17

Coefficients $_{\mathrm{a}}$

\begin{tabular}{|c|c|c|c|c|c|}
\hline \multirow[b]{2}{*}{ Model } & \multicolumn{2}{|c|}{$\begin{array}{l}\text { Unstandardized Coef } \mathrm{f} \\
\text { icients }\end{array}$} & \multirow{2}{*}{\begin{tabular}{|c|}
$\begin{array}{l}\text { Standardized } \\
\text { Coef f icients }\end{array}$ \\
Beta
\end{tabular}} & \multirow[b]{2}{*}{$\mathrm{T}$} & \multirow[b]{2}{*}{ Sig. } \\
\hline & B & $\begin{array}{l}\text { Std. } \\
\text { Error }\end{array}$ & & & \\
\hline $\begin{array}{ll}1 & \text { (Constant) } \\
\text { Kompetensi aparatur } \\
\text { pemerintah }\end{array}$ & $\begin{array}{r}32.433 \\
.324\end{array}$ & $\begin{array}{r}6.291 \\
.098\end{array}$ & .420 & $\begin{array}{l}5.156 \\
3.304\end{array}$ & $\begin{array}{l}.000 \\
.002\end{array}$ \\
\hline
\end{tabular}

a. Dependent Variabel : kualitas pelayanan publik

Sumber : Pengolahan data dengan SPSS for windows ver. 17

Berdasarkan hasil uji yang dapat dilihat pada hasil perhitungan regresi, hasil perhitungan hipotesis melalui uji $t$ diperoleh nilai t hitung sebesar 3.304, dari hasil pengujian dengan tingkat kepercayaan $(\alpha)=0,05$ dan derajat kebebasan (df) n-k-1 atau 53-1-1= 51 ( $\mathrm{n}$ adalah jumlah kasus dan $\mathrm{k}$ adalah jumlah variabel independen) diperoleh $t$ tabel sebesar 1.675, sehingga dapat disimpulkan bahwa $t_{\text {hitung }}>\mathrm{t}_{\text {tabel }}, 3.304>1.675$ sehingga hipotesis yang diajukan diterima.

\section{c. Uji Pengaruh X Terhadap $Y$}

Pengujian hipotesis dengan menggunakan uji $t$ dengan memasukkan nilai hasil perhitungan regresi linier sederhana ke dalam uji t. Hipotesis yang ditawarkan :

$\mathrm{H}_{0} \quad$ : Kompetensi aparatur pemerintah tidak berpengaruh signifikan terhadap kualitas pelayanan publik kecamatan sangatta selatan.

$\mathrm{H}_{\mathrm{a}} \quad$ : Kompetensi aparatur pemerintah berpengaruh signifikan terhadap kualitas pelayanan publik kecamatan sangatta selatan.

Variabel X (Kompetensi aparatur pemerintah) menunjukkan t hitung lebih besar dari pada t tabel yaitu 3.304 > 1.675 maka Ho ditolak, artinya secara parsial ada pengaruh yang 
signifikan antara $\mathrm{X}$ (Kompetensi aparatur pemerintah) dengan kualitas pelayanan publik kecamatan sangatta selatan. Dapat disimpulkan bahwa secara parsial $\mathrm{X}$ (Kompetensi aparatur pemerintah) berpengaruh positif terhadap kualitas pelayanan publik.

\section{Pembahasan}

Hasil perhitungan hipotesis melalui uji t diperoleh t hitung untuk variabel Kompetensi aparatur pemerintah sebesar 3.304 dimana t hitung lebih besar dari t tabel (3.304 > 1.675), maka dapat disimpulkan bahwa Kompetensi aparatur pemerintah secara parsial berpengaruh terhadap kualitas pelayanan publik kecamatan sagatta selatan kabupaten kutai timur.

Hasil pengujian secara parsial pada variabel bebas yaitu variabel Kompetensi aparatur pemerintah terhadap variabel kualitas pelayanan publik menunjukkan hasil yang berpengaruh siginifikan yaitu dengan ditunjukkan dari nilai t hitung > t tabel, $3.304>1675$. Dengan R yang diperoleh sebesar 0.776, yang artinya bahwa $77.6 \%$ Kompetensi aparatur pemerintah mempunyai pengeruh yang positif terhadap kualitas pelayanan dan $22.4 \%$ dipengaruhi oleh faktor lain yang tidak dibahas dalam penelitian ini.

Dengan adanya peningkatan kompetensi pada tiap-tiap aparatur pemerintah maka akam dapat meningkatkan kualitas pelayanan publik. Karena pelayanan publik yang berkualitas maka masyarkaat akan merasa di perhatikan dan dipuaskan.

\section{IV.PENUTUP}

\section{A. Kesimpulan}

1. Hasil pengujian secara parsial pada variabel bebas yaitu variabel Kompetensi aparatur pemerintah terhadap variabel kualitas pelayanan publik menunjukkan hasil yang berpengaruh siginifikan yaitu dengan ditunjukkan dari nilai t hitung > t tabel, $3.304>1675$. Dengan $R$ yang diperoleh sebesar 0.776 , yang artinya bahwa $77.6 \%$ Kompetensi aparatur pemerintah mempunyai pengeruh yang positif terhadap kualitas pelayanan dan $22.4 \%$ dipengaruhi oleh faktor lain yang tidak dibahas dalam penelitian ini.

2. Dengan adanya peningkatan kompetensi pada tiap-tiap aparatur pemerintah maka akam dapat meningkatkan kualitas pelayanan publik. Karena pelayanan publik yang berkualitas maka masyarkaat akan merasa di perhatikan dan dipuaskan. 


\section{B. Saran}

1. Kompetensi pegawai dalam pembahasan ditemukan bahwa pengetahuan pegawai perlu lebih diperhatikan lagi. Pegawai kecamatan perlu adanya pelatihan mengenai ketrampilan komputer dan tanggungjawab dalam bekerja baik itu pelatihan di luar maupun pelatihan yang diadakan sendiri oleh kantor, sehingga dapat menambah pengetahuan mereka dan meningkatkan keterampilan pegawai kecamatan agar lebih baik lagi sesuai dengan perkembangan yang ada.

2. Fasilitas kantor perlu ditambah lagi guna menunjang aktifitas dalam melakukan pelayanan. Kelengkapan fasilitas alat kantor seperti ketersediaan komputer untuk lebih sering dimanfaatkan pegawai guna menunjang kelancaran dan kemudahan dalam penerbitan KK, selain itu perlu disediakan buku pengunjung dan alat tulis yang masih dalam keadaan baik sehingga kualitas pelayanan yang diberikan lebih baik lagi.

\section{BIBLIOGRAFI}

Atik, Ratminto. 2005. Manajemen Pelayanan. Jakarta: Pustaka Pelajar.

Danim, Sudarman. 2004. Motivasi Kepemimpinan dan Efektifitas Kelompok. Rineka Cipta, Jakarta.

Fathoni, Abdurrahmat. 2006. Organisasi dan Manajemen Sumber Daya Manusia. Jakarta: PT Asdi Mahasatya.

Ghazali, Imam. 2011. Aplikasi Analisis Multivariate dengan Program IBM SPSS 19. Semarang: Badan Penerbit Universitas Diponegoro.

Hasibuan, Melayu S.P. 2009. Manajemen Sumber Daya Manusia. Bumi Aksara, Jakarta.

Istianto, Bambang. 2011. Manajemen Pemerintahan dalam Perspektif Pelayanan Publik. Jakarta: Mitra Wacana Media.

Jafar, Farida. 2005. Manajemen Jasa. Jakarta: Ghalia Indonesia.

Lupiyoadi, Rambat dan A. Hamdani. 2006. Manajemen Pemasaran Jasa. Jakarta: Salemba Empat.

Mangkunegara, Anwar P. 2009. Manajemen Sumber Daya Manusia Perusahaan. Bandung: PT Remaja Rosdakarya.

Moenir, A.S. 1987. Pendekatan Manusiawi dan Organisasi terhadap Pembinaan Kepegawaian. Jakarta: Gunung Agung. 
2001. Manajemen Pelayanan Umum Di Indonesia. Jakarta: PT Bumi Aksara.

Moleong, Lexy J. 2006. Metodologi Penelitian Kualitatif. Bandung: PT. Remaja Rosdakarya.

Siagian, Sondang P. Manajemen Sumber Daya Manusia.1991. Jakarta: Bumi Aksara.

Sinambela, Lijan Poltak. 2012. Kinerja Pegawai Teori Pengukuran dan Implikasi. Yogyakarta: Graha Ilmu.

Simamora, Henry. 2006. Manajemen Sumber Daya Manusia. Jakarta: STIE YKPN.

Sudarmanto. 2009. Kinerja dan Pengembangan Kompetensi SDM Teori, Dimensi, dan Implementasi dalam Organisasi. Yogyakarta: Pustaka Pelajar.

Sugiyono. 2010. Metode Penelitian Bisnis Pendekatan Kuantitatif Kualitatif dan $R \& D$. Bandung: Alfabeta

------------2010. Metode Penelitian Pendidikan Kuantitatif Kualitatif dan $R \& D$. Bandung: Alfabeta.

Suharsimi Arikunto 2006. Prosedur Penelitian Suatu Pendekatan Praktik. Jakarta: PT Rineka Cipta.

Sutrisno, Edi. 2009. Manajemen Sumber Daya Manusia. Jakarta: Kencana.

Tjiptono, Fandy.2011. Service Management Mewujudkan Layanan Prima. Yogyakarta:Andi Yogyakarta.

Umar, Husein. 2003. Metode Riset Perilaku Organisasi. Jakarta: Gramedia Pustaka Utama.

Wibowo. 2007. Manajemen Kinerja. Jakarta: Rajawali Pers.

Wirawan. 2009. Evaluasi Kinerja Sumber Daya Manusia Teori, Aplikasi, dan Penelitian. Jakarta: Salemba Empat. 